\author{
高密度光ディスク用光導波路型SHG青色レーザー \\ 北岡 康夫, 鳴海 建治, 水内 公典, 山本 和久, 横山 敏史, 加藤 誠 \\ 松下電器産業 (株) 光ディスク開発センター（テ 570-8501 大阪府守口市八雲中町 3-1-1)
}

\title{
Waveguide-Type SHG Blue Laser for High-Density Optical Disk System
}

\author{
Yasuo KITAOKA, Kenji NARUMI, Kiminori MIZUUCHI \\ Kazuhisa YAMAMOTO, Toshifumi YOKOYAMA, and Makoto KATO \\ Matsushita Electric Industrial Co., Ltd., Optical Disk Systems Development Center \\ 3-1-1 Yagumo-Nakamachi, Moriguchi, Osaka 570-8501
}

(Received November 27, 1997)

\begin{abstract}
A high power SHG blue laser with direct modulation capability at high frequency has been demonstrated using a tunable distributed Bragg reflector (DBR) laser diode and a waveguide-type quasi-phase-matched second harmonic generation (QPM-SHG) device in X-cut $\mathrm{Mg}$ doped $\mathrm{LiNbO}_{3}$. Continuous blue light power of $12 \mathrm{~mW}$ and pulsed peak power of $26 \mathrm{~mW}$ were generated. The SHG blue laser was installed to an optical head, and readout of ROM disk and recording on phase change optical disk were performed. A butt-coupling-type $0.8 \mathrm{cc}$ SHG blue laser was also fabricated. It was indicated that SHG blue laser is applicable to high-density optical disk system.
\end{abstract}

Key Words: Second harmonic generation, Quasi-phase-matching, Waveguide, Butt-coupling, Optical disk system

1.はじめに

赤色半導体レーザー (AlGaInP系, 波長650nm)の実現によ り, ディジタルオーディオ CDに比べて7倍以上高密度の DVDが開発・商品化され,光ディスクでも映像を扱う時代 となった＼cjkstart高精細画像の情報を光ディスクに記録したり， 現行のビデオテープの置き換えを考え4時間以上の録画時 間を得るためには10GB以上の記録容量が必要とされる。 光ディスクの高密度化技術として, (1) 光源の短波長化, (2) レンズの高NA(Numerical Aperture)化などがある.

我々は, 短波長光源を用いた光ディスクシステムの高密 度化に着目してきた。 $12 \mathrm{~cm}$ 径のディスクに10GB以上の記 録容量を実現するためには青色領域の光源が必要であり, 青色レーザー実現の1つのアプローチとして, 波長変換デバ イスを用いた赤外半導体レーザーの第2高調波発生 (Second Harmonic Generation: SHG)による400nm帯の光源開発を 行ってきた. 光ディスク用光源として要望される仕様に, (1) $10 \mathrm{~mW}$ 以上の出力, (2) $-135 \mathrm{~dB} / \mathrm{Hz}$ 以下の低ノイズ, (3) 回折限界での集光, (4) 数 $10 \mathrm{MHz}$ 以上の高速変調, (5) $1 \mathrm{cc}$ 以下の小型化などがある．上記仕様を満足する青色光源 を実現するため, 光導波路型波長変換デバイスと光フィー ドバックにより発振波長がロックされた半導体レーザー により構成される直接波長変換方式の青色光源を提案し てきた. 光導波路型波長変換デバイスを用いた構成では, 大きな光閉じこめ効果および長い相互作用長による高効
率波長変換, および青色光が導波モードであることによる 良好な集光特性が期待できる1-4)。また, 光フィードバック 機能が集積化されたDistributed Bragg Reflector(DBR) 型半 導体レーザーを基本波として用いることにより,低ノイズ 化および小型化が期待できる。ささらに, 固体レーザーなど を用いない直接波長変換であるため, 波長変換により得ら れる青色光の高速直接変調も可能となる.

今回, $\mathrm{MgO}: \mathrm{LiNbO}_{3}$ 基板を用いた高効率光導波路型波長 変換デバイスと高出力波長可変DBR半導体レーザーを開 発し, 直接変調可能な $10 \mathrm{~mW}$ 以上の高出力青色レーザー (426nm)を実現し, その諸特性について検討した。また, 結 合レンズを削除した直接結合特性についても検討し, 1 cc以 下の超小型SHG青色レーザーを実現した。 さらに, SHG青 色レーザーを光ピックアップに搭載し, 相変化光ディスク 上に15GB相当の単一マーク記録を行ったので報告する.

\section{SHG 青色レーザー}

2.1 構 成

提案するSHG青色レーザーは, Fig.1に示すように赤外の 波長可変DBR半導体レーザーと光導波路型擬似位相整合 方式 (Quasi-Phase-Matched: QPM)-SHGデバイスから構成さ れる。SHG青色レーザーにおいて高効率波長変換を実現 するためには, 半導体レーザーの波長をQPM-SHGデバイス の位相整合波長に一致させる必要がある。我々は従来よ 
り,グレーティングや狭带域バンドパスフィルタなどを用 いて光フィードバックによる半導体レーザーの波長ロッ ク検討を行ってきた ${ }^{5)}$. 本論文では, 波長ロック機能が集 積化された波長可变DBR半導体レーザー(出力：100mW, 波長 $852 \mathrm{~nm}$ ) を基本波光源として用いた。 SHGデバイスに は, $\mathrm{x} カ ッ \mathrm{MgO}: \mathrm{LiNbO}_{3}$ 基板上に周期的分極反転領域とプ ロトン交換光導波路を形成した光導波路型QPM-SHGデバ イスを用いた。

波長可変DBR半導体レーザーは, 独立した電極を有する 活性領域とDBR領域から構成される。DBR領域には回折 格子が形成され, レーザー波長を回折格子のBragg波長に固 定する。また, DBR 領域へ電流注入することにより DBR 領 域の屈折率変化を与え, 発振波長を可変することが可能で ある.この波長可変DBR半導体レーザーは6), 本SHG青色 レーザーへ応用するためにSDL社(米国)により開発された ものである。DBR領域に波長制御電流として $100 \mathrm{~mA}$ を注 入した時, 単一縦モードを維持しながら波長可変範囲 $2 \mathrm{~nm}$ が得られた。また,しきい值 $16 \mathrm{~mA}$, 動作電流140mAに対し, $100 \mathrm{~mW}$ 出力が得られた。

次に, 光導波路型QPM-SHGデバイスの構成について説 明する，基板として用いた $\mathrm{MgO}: \mathrm{LiNbO}_{3}$ は, 短波長光が照 射されたときに屈折率変化が生じる現象 (光損傷)に関して その変化量が小さく7), 高出力の青色光発生の目的に有効 な結晶基板である。 また, 非線形光学定数も大きく, 高い 変換効率が期待できる．光導波路型QPM-SHGデバイスに おいて高効率波長変換を実現するため, 基本波と高調波の オーバーラップを大きくし,かつ深い分極反転領域を形成 する必要がある。本論文では,半導体レーザーとの直接結 合を容易にするため, 結晶基板にはx板(TEモード伝搬)を 用いた。我々は, $\mathrm{x}$ 板上に深い周期的分極反転領域を形成可 能な 2 次元電界印加法を開発し ${ }^{8)}$, 深さ $1.3 \mu \mathrm{m}$, 周期 $3.2 \mu \mathrm{m}$ の 分極反転層を $10 \mathrm{~mm}$ 長にわたり均一に実現した。また, 周 期的分極反転領域と垂直方向に形成されたプロトン交換 光導波路上に高屈折率クラッド層を形成し, 基本波の閉じ 込めをよくすることで, 高調波とのオーバーラップ,すな わち变換効率の向上を実現した ${ }^{9)}$. 光導波路の導波損失は $1 \mathrm{~dB}$ 以下であった。

\subsection{SHG特性}

波長可変DBR半導体レーザーと光導波路型QPM-SHGデ バイスを一体モジュール化し, その諸特性を調べた. xカッ 卜基板上に形成されたプロトン交換光導波路は, 半導体 レーザーの偏光方向と同じTEモードの基本波を導波させ ることが可能なので, 半波長板なしで半導体レーザー光を 光導波路内に効率よく結合することができる. 結合レン ズを選択し, 半導体レーザーの集光スポットを光導波路の 横モードに一致させることにより, 高結合効率50\%を実現 した. Fig.2に, SHG出力特性を示す。横軸は光導波路内に 結合した半導体レーザー出力, 縦軸は青色出力を示す. DBR 領域 (波長可変部)への電流注入により, 波長可変DBR 半導体レーザーの波長を光導波路型QPM-SHGデバイスの 位相整合波長に一致させ, 光導波路への半導体レーザー入 力 $50 \mathrm{~mW}$ に対し $12 \mathrm{~mW}$ (連続光) 青色光を得, 変換効率 $20 \%$ を
実現した，青色出力の安定性は, 10時間に対して土5\%であ り, 光損傷による出力変動は観測されなかった. 測定され た青色光の相対雑音強度は- $144 \mathrm{~dB} / \mathrm{Hz}$ であり, 光ディスク 用光源として十分低いノイズレベルが得られた。

次に, 波長可変DBR半導体レーザーのDBR領域(波長可 変部)への電源注入によるSHG青色レーザーの立ち上げ制 御を検討した。波長可変DBR半導体レーザーは, 動作電流 一定 $(\mathrm{ACC})$ で駆動した。はじめに, DBR 領域への注入電流 を0 $0 \mathrm{~mA} ら 80 \mathrm{~mA}$ まで走査し, Fig.1に示すように得られた 青色光をフォトディテクターで検出し, 青色出力が最大に なる注入電流 $\left(\mathrm{I}_{\mathrm{dbr}}\right)$ をメ干リーに記憶する。次に, 注、入電流 を $\mathrm{I}_{\mathrm{dbr}}$ に調整し, 青色出力を安定化する.1.3秒程度の制御時 間で, SHG青色レーザーを立ち上げ安定化することができ た. 波長可変DBR半導体レーザーを基本波として用いる ことにより,電気的なフィードバック制御が可能となり, 高 速での立ち上がり特性を実現することができた。

青色光の直接変調特性について説明する. 本論文では, 外部変調器を用いない半導体レーザーの駆動電流を直接 変調したときの青色光変調特性について検討した。一般 のファブリペロー半導体レーザーでは, その駆動電流を変 調すると,マルチ縦モード発振が生じる。QPM-SHGデバイ スは, 高効率波長変換を実現するための位相整合波長に対 する許容幅が $0.1 \mathrm{~nm}$ 程度と小さいため, この基本波である半 導体レーザーの縦モード広がりは変換効率の低下をまね く，基本波として波長可変DBR半導体レーザーを用いる ことにより, 縦モードの広がりは抑制される. Fig.3は, 波 長可変DBR半導体レーザーと光導波路型QPM-SHGデバイ

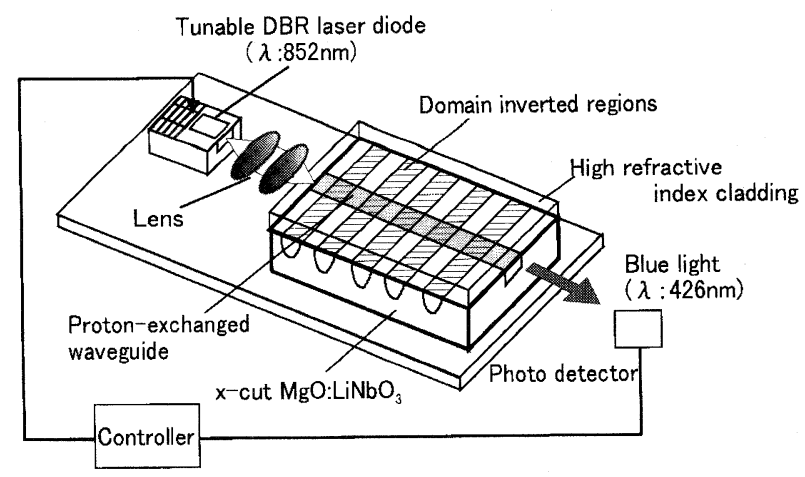

Fig.1 Configuration of a SHG blue laser.

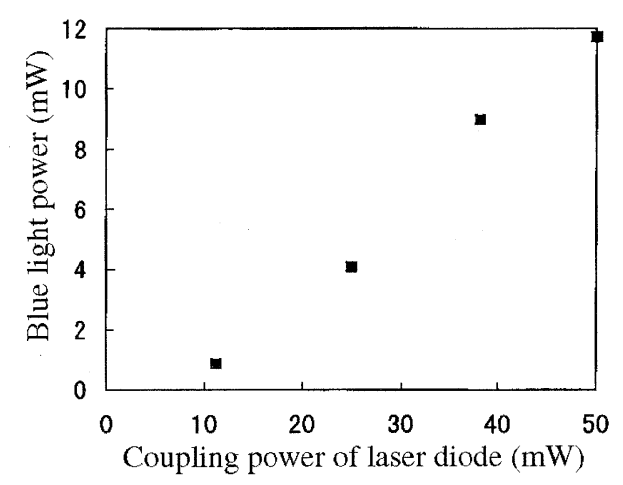

Fig.2 Generated blue light power as a function of coupling laser diode power in the waveguide. 


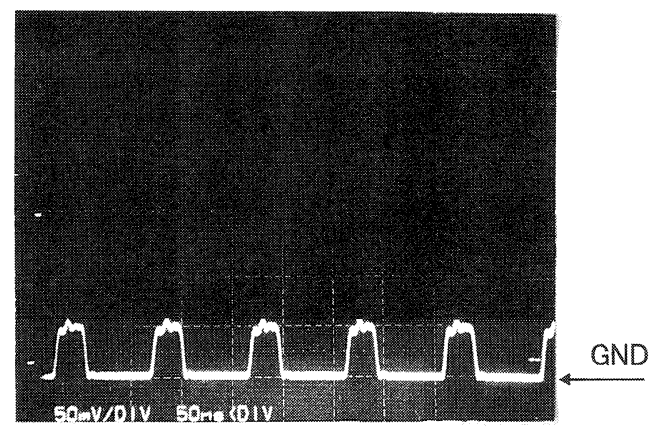

50 ns / div

Fig.3 Output waveform for blue light of directly modulated SHG blue laser.

スから構成されたSHG青色レーザーの青色光の出力変調 波形を示している。変調周波数は $10 \mathrm{MHz}$ (duty: 33\%)であ る. 光導波路への半導体レーザーピーク入力 $115 \mathrm{~mW}$ に対

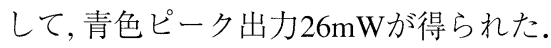

以上の結果, 波長可変DBR半導体レーザーと光導波路型 QPM-SHGデバイスから構成されたSHG青色レーザーは， 出力, 出力安定性, ノイズ, 変調特性など光ディスクの仕様 を満足し,光デイスク応用に適した青色光源であることが 示された。

\section{3 小型化}

結合レンズを用いたモジュール構成では, 超小型化 (1 $1 \mathrm{cc}$ 以下）および量産化可能な工法を実現することは困難であ る. 光通信分野では, 小型実用化を目指して半導体レー ザーと光ファイバの直接結合による実装検討が活発に行 われている(10). 波長可変DBR半導体レーザーは光フィー ドバック機能が集積化されているため, 直接結合による超 小型のモジュール構成が可能となる。

我々は従来より,zカット $\mathrm{LiTaO}_{3}$ 基板上に作製した光尊波 路型QPM-SHGデバイスの入射端面に $\mathrm{Ta}_{2} \mathrm{O}_{5}$ 半波長膜を形 成し,半導体レーザーとの直接結合特性について検討して きた ${ }^{11)}$ 。 xカット $\mathrm{MgO}: \mathrm{LiNbO}_{3}$ 基板上のプロトン交換光導 波路は, 半波長板なしで半導体レーザー光を導波すること ができるため,直接結合型モジュールには有利である。波 長可変DBR 半導体レーザーと $\mathrm{MgO}: \mathrm{LiNbO}_{3}$ 光導波路型 QPM-SHGデバイスの直接結合において, 半導体レーザー出 射端面と光導波路入射端面の距離が1 $\mu \mathrm{m}$ 以下の時, $70 \%$ の 高結合効率を実現した. Fig.4の右側に示されるのは, 試作 した直接結合型SHG青色レーザーである。サイズは $0.8 \mathrm{cc}$ である. 左側は通常のAlGaAs半導体レーザー $(9 \mathrm{~mm} \phi$ ステ 厶実装)である. 室温近傍では, 温度制御なしで安定な動作 を確認している。半導体レーザー端面と光導波路端面の 距離は $5 \mu \mathrm{m}$ で固定され, 結合効率 $35 \%$ に対し青色出力 $2 \mathrm{~mW}$ が得られた。

直接結合型 $\mathrm{SHG}$ 青色レーザーの試作より, $\mathrm{Si}$ サブマウン ト上に半導体レーザーチップとQPM-SHGデバイスを実装 したプレーナータイプの直接結合モジュール実現への可 能性が見い出せ, さらに小型で量産可能なSHG青色レー ザーの実現可能性が示された。

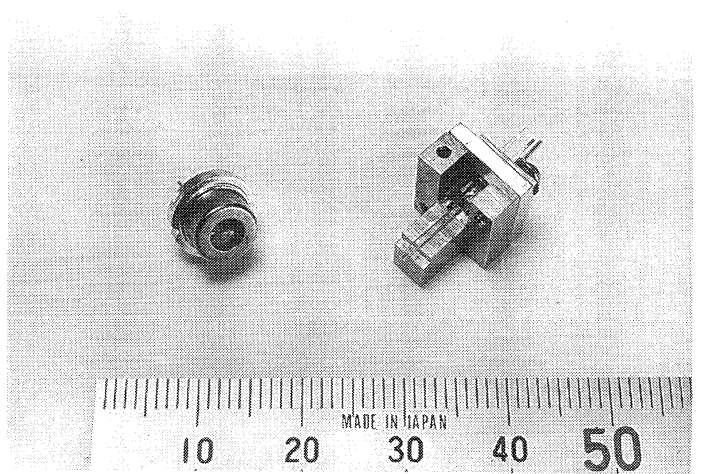

Fig.4 Butt-coupling type SHG blue laser with a size of 0.8 cc, compared with conventional AlGaAs laser diode.

\section{3. 光ディスクへの応用}

\section{1 光ピックアップの構成}

SHG青色レーザーを搭載した光ピックアップを試作し, 光ディスクへの忘用について検討した．Fig.5に光ピック アップの構成を示す.SHG青色レーザーから出射された 光は, レンズによりコリメートされ,プリズムペアーによ りビーム形成される。ビーム整形されたビームは, 偏光 ビームスプリッタ $(\mathrm{PBS})$ を透過し, 反射プリズムで入/4板と 対物レンズに導かれる。対物レンズは基材厚 $0.6 \mathrm{~mm}$ 用の $N A=0.6$ 非球面レンズである。ディスクで反射したビー ムは,PBSで反射し,検出レンズとシリンドリカルレンズを 透過後, フォトディテクター上に導かれる。フォトディテ クター表面には, 青色領域に最適化した無反射コートが形 成されている。フォーカスサーボ信号は非点収差法で, 卜 ラッキングサーボ信号はプッシュプル法抒よび位相差法 で検出された。対物レンズ後の青色出力は, 連続動作 $(\mathrm{CW})$ 時で $2.2 \mathrm{~mW}$, 変調動作時でピーク出力 $6 \mathrm{~mW}$ 得られ た. 対物レンズ後の青色光の集光特性を評価したところ, タンジェンシャル・ラジアル方向ともに半值全幅 $0.39 \mu \mathrm{m}$ の回折限界の集光スポットを実現した。

Fig.6は, SHG青色レーザーを搭載した光ピックアップを 用いて, 高密度ROMディスクの (a) 単一信号拈よび $(\mathrm{b})$ ラ ンダム信号,を再生した結果である。単一信号のピット長 は,現行のDVD-ROMデイスクの最短ピット長 $0.40 \mu \mathrm{m} に$ 対

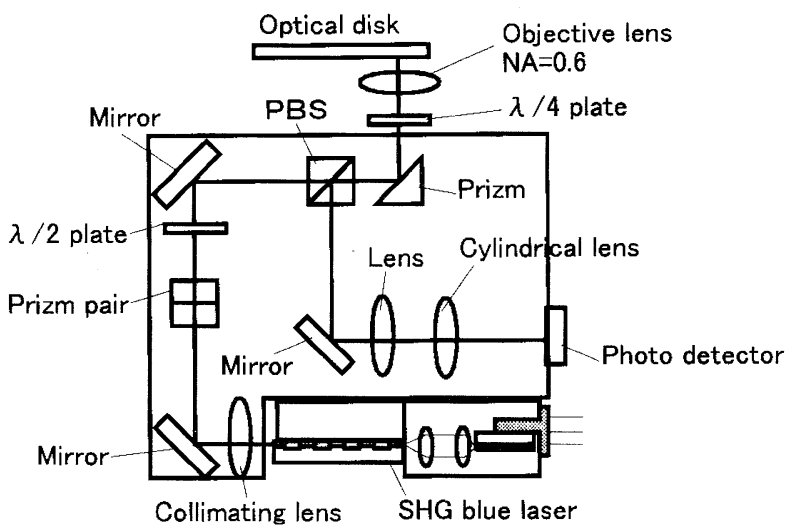

Fig.5 Configuration of an optical pickup with the SHG blue laser. 


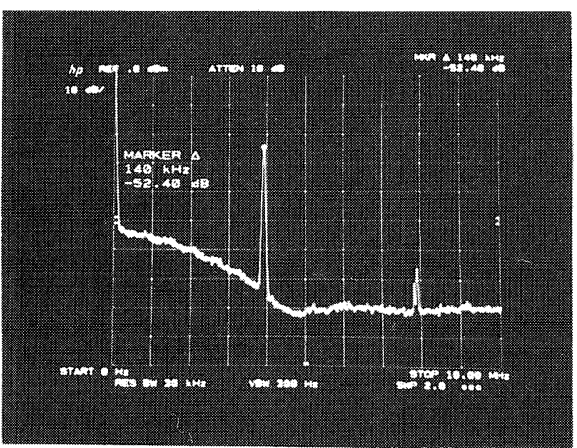

(a)

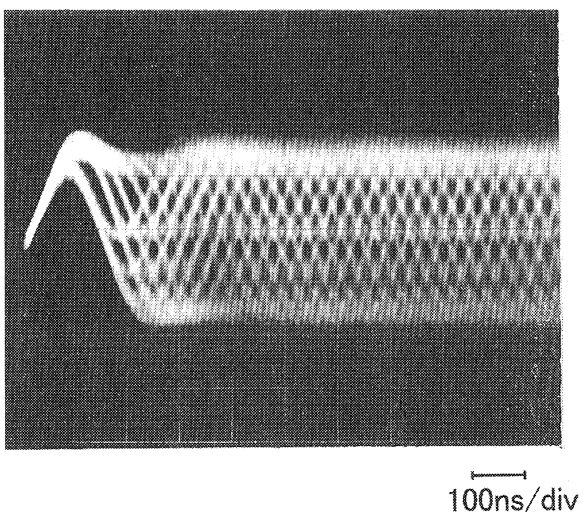

(b)

Fig.6 Readout characteristics of ROM disk by using an optical pickup with the SHG blue laser. (a) for pure tone signal and (b) for random signal.

し, 波長比 $(425 \mathrm{~nm} / 650 \mathrm{~nm})$ で求めた值に設計した。単一信 号のピット長 $0.25 \mu \mathrm{m}$ に対して $\mathrm{C} / \mathrm{N}=52.4 \mathrm{~dB}$ が得られ, SHG 青色レーザーを搭載した光ピックアップの集光特性が回 折限界まで集光でき, 現行の赤色半導体レーザーを用いた DVDと比較しても十分な光学的周波数特性が得られるこ とが示された。一方，(b)はトラックピッチ $0.74 \mu \mathrm{m}$, 最短 マークピット長 $0.29 \mu \mathrm{m}$ (8-15変調)のランダム信号を再生し たアイパターンである。この時, 得られたジッ夕 (data to data）は $11 \%$ あった。今後, ディスクカッティング条件や 光ピックアップ調整の最適化などにより, さらにジッタが 向上すると思われる．SHG青色レーザーを搭載した光 ピックアップにより光ディスクの高密度化が図れ, 光源の 短波長化が10GB以上の高密度光ディスクシステム実現に 有効な手段であることが示された。

\section{2 記録特性}

SHG青色レーザーが搭載された光ピックアップを用い て,相变化光ディスクへの高密度記録再生について検討し た. 実験に用いられた青色用相変化光ディスクの断面構 造をFig.7に示す。基板にはDVDと同じ0.6mm厚のポリ カーボネート基板が用いられ, 基板上にはスペース間隔が $0.33 \mu \mathrm{m}$ おび $0.35 \mu \mathrm{m}$ のランド・グルーブが形成された。 また，基板上に誘電体層 $(\mathrm{ZnS})$ により挟まれた記録層 (GeSbTe) を形成され, 反射層としてはAuが用いられた。

Fig.8は, スペース間隔 $0.33 \mu \mathrm{m}$ のランドおよびグルーブ上 に単一信号記録したマークを透過型電子顕微鏡で観察し

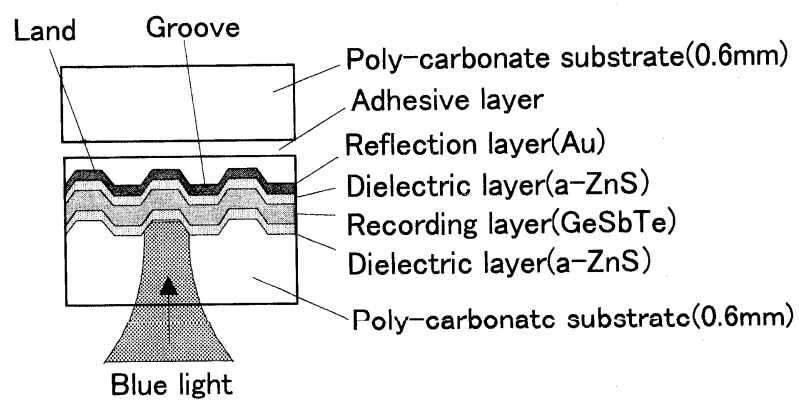

Fig.7 Cross section of phase-change optical disk.

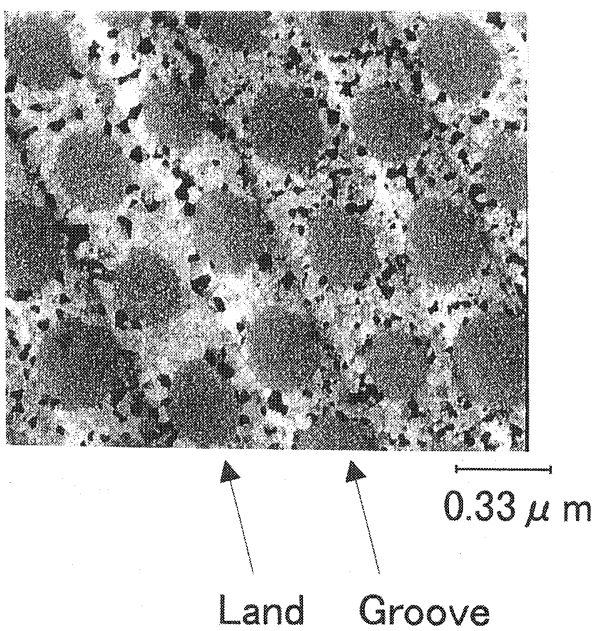

Fig.8 Recorded mark on phase-change optical disk observed by TEM.

た結果である。マーク長 $0.24 \mu \mathrm{m}$ の記録マークがランド . グルーブに形成され, $120 \mathrm{~mm} \phi$ の光ディスクに片面 $15 \mathrm{~GB}$ 相 当の記録密度の単一マーク記録を実現した。また, スペー ス間隔 $0.35 \mu \mathrm{m}$ のグルーブ上にマーク長 $0.3 \mu \mathrm{m}$ の単一信号記 録を行い, 同じSHG青色レーザー光ピックアップで再生し たところC/N=46dBが得られた。

\section{4. まとめ}

波長可変DBR 半導体レーザーと $\mathrm{MgO}: \mathrm{LiNbO}_{3}$ 光導波路型 QPM-SHGデバイスを用いて, 高出力かつ低ノイズで, 高速 变調可能なSHG青色レーザーを実現した。連続動作で $12 \mathrm{~mW}$ 青色出力, 変調動作で $26 \mathrm{~mW}$ のピーク青色出力が得ら れた。また, 直接結合により $0.8 \mathrm{cc} の$ 超小型SHG青色レー ザーを実現した。さらに, SHG青色レーザーを搭載した光 ピックアップを試作し, 高密度ROMディスクの再生特性お よび相変化光ディスクへの記録再生特性について検討し, 良好な記録再生特性が得られた。

我々は, $\mathrm{SHG}$ 青色レーザーの基本波光源として波長可変 DBR半導体レーザーを, また波長変換デバイスとして光導 波路型QPM-SHGデバイスを用いることを提案してきた.

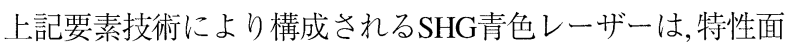
だけでなく小型化の可能性など光ディスクに応用するため の課題を解決できるものとして, その有効性が示された。 
謝 辞

光導波路型QPM-SHGデバイスの作製に協力して頂いた 大西繁喜氏, また光ピックアップの作製および構成に助言 を頂いた伊藤昇氏, 水野定夫氏に感謝致します。高密度 ROMディスクの作製および評価に協力して頂いた阿部伸 也氏, 相変化光ディスクへの記録再生に有意義な助言と多 大なる協力を頂いた西内 健一氏, 植野文章氏に感謝の意 を表します．SHG青色レーザーの出力安定化用制御系を 構築して頂いた高峯浩一氏に感謝致します。

\section{参考文献}

1) K. Mizuuchi and K. Yamamoto: Appl. Phys. Lett. 66 (1995) 2943.

2) S. Sonoda, I. Tsuruma, and M. Hatori: The 57th Autumn Meeting,
1996, The Japan Society of Applied Physics 8p-KG-7.

3) S. Okamoto and T. Tohma: Microoptics News 13 (1995) 31.

4) M. Fujimura, T. Suhara, and H. Nishihara: Electro. Lett. 27 (1991) 1207.

5) Y. Kitaoka, K. Mizuuchi, K. Yamamoto, and M. Kato: Opt. Review 1 (1994) 227.

6) V. M. Gulgazov, H. Zhao, D. Nam, J. S. Major, and T. L. Koch: Electro. Lett. 33 (1997) 58.

7) D. A. Bryan, R. Gerson, and H. E. Tomaschke: Appl. Phys. Lett. 44 (1984) 847.

8) K. Mizuuchi, K. Yamamoto, and M. Kato: Electro. Lett. 33 (1997) 806.

9) K. Mizuuchi, H. Ohta, K. Yamamoto, and M. Kato: Opt. Lett. 22 (1997) 1217.

10) C. A. Armiento, M. Tabasky, C. Jaganath, T. W. Fitzgerald, C. L. Shieh, V. Barry, M. Rothman, A. Negri, P. O. Haugsjaa, and H. F. Lockwood: Electro. Lett. 27 (1991) 1109.

11) Y. Kitaoka, H. Wada, S. Nishino, K. Mizuuchi, K. Yamamoto, and M. Kato: Opt. Review 3 (1996) 481. 